\title{
PERBEDAAN FONOLOGIS BAHASA MELAYU DI DESA CERUK DAN DI PULAU LAUT KABUPATEN NATUNA PROVINSI KEPULAUAN RIAU
}

\author{
Tasliati \\ Kantor Bahasa Kepulauan Riau \\ Pos-el: tasliati@kemdikbud.go.id
}

\begin{abstract}
A bstrak
Penelitian ini bertujuan untuk mendeskripsikan perbedaan fonologis bahasa Melayu di Desa Ceruk dan di Pulau Laut, Kabupaten Natuna, Provinsi Kepulauan Riau. Data berupa 200 kosakata Swadesh dikumpulkan dengan metode simak dan wawancara dengan teknik simak bebas libat cakap (SBLC), teknik rekam, dan teknik catat. Data selanjutnya dianalisis dengan metode padan intralingual dengan teknik hubung-banding. Hasil penelitian menunjukkan bahwa (1) perbedaan berupa korespondensi ditemukan dalam dua bentuk, yaitu korespondensi sangat sempurna dan korespondensi kurang sempurna. Korespondensi sangat sempurna ditemukan dalam enam bentuk perubahan $\varepsilon \approx I, o \approx U, \varepsilon \approx 0, R \approx X, K \approx$, dan $ə \approx a$. Korespondensi kurang sempurna ditemukan dalam tiga bentuk perubahan: $I \approx \mathrm{i}, \varnothing \approx X$, dan $\mathrm{t} \approx \mathrm{d}$. (2) Perbedaan berupa variasi ditemukan dalam empat bentuk: (a) fonem vokal belakang tengah menjadi vokal pusat rendah ( $(\sim a)$, (b) penambahan satu fonem di akhir kata atau protesis ( $\varnothing \sim$ dan $\varnothing \sim a)$, (c) fonem tak bersuara menjadi bersuara $(k \sim g$ dan $p \sim b)$, dan $(d)$ penambahan satu fonem di akhir kata atau paragog $(\varnothing-h$ dan $\varnothing ?)$.
\end{abstract}

Kata kunci: perbedaan fonologis, kajian bahasa M elayu, kajian dialek, Kabupaten Natuna

\begin{abstract}
This study aims to describe phonological differences of $M$ alay language in Ceruk village and Pulau Laut, $\mathrm{N}$ atuna regency, Riau Islands Province The data in the form of 200 Swadesh vocabulary was collected by using referring and interview method with the technique of SBLC and recording. Then, the data were analyzed by intralingual matching method with the connecting and comparing technique. The results show that (1) the differences in the form of correspondence are found in two forms, namely perfect correspondence and unperfect correspondence. The perfect correspondences is found in six forms of change: $\varepsilon \approx I, o \approx U, \varepsilon \approx \partial, R \approx X, K \approx 2$, and $\approx \approx a$. The unperfect correspondence is found in three forms of change $I \approx i$, $\varnothing \approx X$, and $t \approx d$. (2) The differences in the form of variation are found in four forms: (a) the middle rear vowel phoneme becomes the low center vowel ( $a \sim a)$, (b) the addition of one phoneme at the end of a word or protesis $(\varnothing \sim$ dan $\varnothing \sim a)$. (c) the mute phoneme becomes the voiced phoneme ( $k \sim g$ dan $p \sim b)$, and (d) the addition of one phoneme at the end of a word or paragog ( $\varnothing \sim h$ dan $\varnothing$ ?).
\end{abstract}

Keyw ords: phonological differences, M alay languagestudy, study of dialect, $N$ atuna R egency

\section{PENDAHULUAN}

Kabupaten $\mathrm{N}$ atuna secara astronomis terletak antara $01^{\circ} 18^{\prime} 00^{\prime \prime}$ sampai $06^{\circ} 50^{\prime} 15$ lintang utara, serta antara $104^{\circ} 48^{\prime} 30^{\prime \prime}$ sampai dengan $110^{\circ} 04^{\prime} 00$ bujur timur. Secara geografis, Kabupaten Natuna mempunyai batasbatas yang meliputi: di utara berbatasan Laut
Natuna Utara, di Selatan berbatasan dengan Kabupaten Bintan, di Barat Semenanjung Malaysia, dan di timur berbatasan dengan Laut Natuna Utara. Kabupaten Natuna memiliki luas $224.684,59 \mathrm{~km}^{2}$. Dari luas tersebut, hanya $2.001,30 \mathrm{~km}^{2}$ yang merupakan daratan, selebihnya $222.683,29 \mathrm{~km}^{2}$ merupakan lautan 
(BPS Natuna, 2017:1). A rtinya, 99\% wilayah Kabupaten Natuna merupakan Iautan. Wilayah Kabupaten Natuna yang terdiri atas 15 kecamatan dan 76 desa/ kelurahan ini terdiri atas pulau-pulau yang sebagian besar belum berpenghuni. Dari 154 pulau yang ada di Kabupaten Natuna, baru 27 pulau yang berpenghuni (BPS Natuna, 2017:17). Mayoritas penduduk yang tinggal di Kabupaten Natuna adalah suku Melayu yang sehari-hari menggunakan bahasa M elayu untuk berkomunikasi.

Berdasarkan pengakuan masyarakat, bahasa Melayu yang digunakan di satu desa terdengar berbeda dengan bahasa M elayu di desa lain yang masih berada di Kabupaten Natuna. Salah satunya adalah bahasa Melayu yang digunakan oleh masyarakat di Desa Ceruk de ngan di Pulau Laut. Dilihat dari letaknya dari ibukota kabupaten, kedua daerah ini berjarak cukup jauh, jarak Ceruk ke Ranai adalah 25 Km, sedangkan jarak Pulau Laut ke Ranai 118 Km (BPS N atuna, 2017:19). Melihat jarak yang jauh tersebut, wajar saja apabila bahasa yang digunakan di kedua daerah ini memiliki perbedaan. A pakah perbedaan tersebut dapat dikategorikan sebagai bahasa yang berbeda, dialek yang berbeda, atau hanya pada tataran subdialek? Hal itu dapat ditentukan melalui penelitian kekerabatan dan pemetaan bahasa di Kabupaten Natuna.

Dalam makalah ini, pembahasan tidak sampai pada penentuan status kekerabatan kedua isolek, melainkan terbatas pada deskripsi unsur kebahasaan berupa perbedaan fonologis. Deskripsi mengenai perbedaan fonologis dinilai penting mengingat deskripsi perbedaan pada tataran fonologi ini merupakan dasar dalam menentukan bahasa yang berkerabat, yaitu lewat perbandingan fonem-fonem dari kosakata yang dianggap berasal dari purba yang sama. Sejalan dengan hal itu, makalah ini bertujuan untuk mendeskripsikan perbedaan fonologis bahasa Melayu di Desa Ceruk dan Pulau Laut.

\section{TEORI DAN METODE}

Penelitian ini dilandaskan pada teori dialektologi dan linguistik historis komparatif. Teori dialektologi digunakan untuk mendeskripsikan perbedaan unsur kebahasaan yang terdapat pada kedua daerah pengamatan. Sementara teori linguistik historis komparatif digunakan untuk menentukan bentuk purba dari kosakata yang dibandingkan. Penggabungan dialektologi dan linguistik historis komparatif ini disebut dengan istilah dialektologi diakronis (Mahsun, 1995:11). Dalam hal ini, perbedaan unsur kebahasaan dibatasi pada perbedaan fonologis.

Bentuk-bentuk yang dianggap berbeda secara fonologis pada prinsipnya adalah bentuk yang dapat dihubungkan pada sebuah bentuk bahasa purba yang sama. A pabila perbedaannya tidak dapat dihubungkan dengan bentuk purba yang sama, perbedaan tersebut sudah termasuk perbedaan leksikal. Perbedaan dalam tataran fonologis ini dapat dibedakan berdasarkan sifatnya. Perubahan yang sifatnya teratur disebut korespondensi, dan perubahan yang sifatnya tidak teratur (sporadis) disebut variasi.

Korespondensi dapat dibedakan menjadi tiga: korespondensi sangat sempurna, sempurna, dan kurang sempurna. Korespondensi dikatakan sangat sempurna apabila perbedaan yang disebabkan oleh perubahan bunyi itu terjadi pada semua data yang disyarati oleh kaidah perubahan serta sebaran geografisnya sama. Pada korespondensi sempurna, perbedaan juga terjadi pada semua data yang disyarati oleh kaidah perubahan, tetapi sebaran geografis antarcontoh berbeda. Adapun yang termasuk korespondensi kurang sempurna apabila perbedaan akibat perubahan bunyi terjadi pada 2-5 contoh dengan sebaran geografis yang sama. Sementara itu, perbedaan disebut variasi apabila kaidah perubahan bunyi hanya terjadi pada satu atau dua contoh dengan sebaran geografis yang berbeda. Perbedaan yang termasuk variasi dapat berupa metatesis, 
asimilasi, disimilasi, apokop, sinkop, aferesis, kontraksi, dan Iain-lain (Mahsun, 1995:34).

Adapun metode yang digunakan dalam penelitian ini disesuaikan dengan tahap penelitian yang dilakukan. (1) Pada tahap pengumpulan data, metode yang digunakan adalah metodemetode simak, dengan teknik simak bebas libat cakap (SBLC) (Sudaryanto, 1993:133140. Artinya, peneliti tidak ikut terlibat dalam pengumpulan data karena data yang dianalisis merupakan data sekunder dari penelitian se belumnya. Data tersebut dikumpulkan dengan menggunakan instrumen daftar tanyaan 200 kosakata Swadesh. Untuk menguatkan data yang diperoleh, dilakukan verifikasi kepada penutur jati dengan teknik wawancara yang disertai dengan teknik rekam dan teknik catat (lihat Sudaryanto, 1993:133-140). (2) Pada tahap analisis data, metode yang digunakan adalah metode padan. Metode padan yang digunakan dalam penelitian ini adalah metode padan intralingual. Metode padan ini menggunakan teknik hubung banding membedakan dan menyamakan (Kesuma, 2007:49). Dari penerapan metode tersebut didapatkanlah hasil mengenai perbedaan fonologis di kedua daerah pengamatan.

\section{HASIL DAN PEMBAHASAN}

Berdasarkan data yang diperoleh melalui perbandingan 200 kosakata Swadesh bahasa Melayu di Desa Ceruk dan Pulau Laut, ditemukan adanya perbedaan-perbedaan fonologis, baik perbedaan berupa korespondensi, yaitu perbedaan yang sifatnyateratur maupun variasi, maupun perbedaan yang sifatnya tidak teratur (sporadis). Oleh karena itu, pada bagian pembahasan ini dijelaskan mengenai empat hal (1) korespondensi vokal, (2) korespondensi konsonan, (3) variasi vokal, dan (4) variasi konsonan.

\subsection{Korespondensi Vokal}

Korespondensi vokal yang ditemukan dalam bahasa M elayu di Desa Ceruk dan Pulau Laut adalah sebagai berikut.

\subsection{1 $\varepsilon \approx \mathrm{I} / \mathrm{-K}(\mathrm{V}) \mathrm{K \#}$}

Fonem $\varepsilon$ di daerah pengamatan Ceruk berkorespondensi dengan fonem I di daerah pengamatan Pulau Laut pada posisi ultima (suku kata akhir) yang letaknya berada di antara konsonan. Korespondensi yang terjadi dapat dikategorikan sebagai korespondensi sangat sempurna karena variasi fonem $\varepsilon$ menjadi I terjadi pada semua data yang disyarati oleh kaidah $_{\varepsilon} \approx \mathrm{I} / \mathrm{-K}(\mathrm{V}) \mathrm{K} \#$ dengan sebaran geografis yang sama. Berikut ini adalah tiga contoh sebagai evidensi data yang menunjukkan perbedaan fonologis tersebut.

Tabel 1. Evidensi D ata $\varepsilon \approx \mathrm{I} /-\mathrm{K}(\mathrm{V}) \mathrm{K} \#$

\begin{tabular}{|l|l|l|l|}
\hline No. & \multicolumn{1}{|c|}{ Glos } & \multicolumn{1}{c|}{ Ceruk } & Pulau Laut \\
\hline 1 & Gigit & giget & gigIt \\
\hline 2 & Jahit & jayet & jowIt \\
\hline 3 & Kuning & kunen & kunIn \\
\hline
\end{tabular}

Data pada tabel 1 menunjukkan bahwa pertama, glos gigit / giget/ di daerah pengamatan Ceruk berkorespondensi / giglt/ di daerah pengamatan Pulau Laut. Kedua, glos jahit / jayet/ di daerah pengamatan Ceruk berkorespondensi dengan / jowlt/ di daerah pengamatan Pulau Laut. Ketiga, glos kuning / kun $\mathrm{y} /$ di daerah pengamatan Ceruk berkorespondensi dengan / kunly/ di daerah pengamatan Pulau Laut. Korespondensi fonem $\varepsilon$ menjadi I terletak pada suku kata akhir yang posisinya berada di antara konsonan. Pada contoh pertama, letak perubahan fonem vokal berada di antara konsonan g dan t. Pada contoh kedua, letaknya berada di antara konsonan y dan t, kemudian pada daerah pengamatan Pulau Laut, fonem konsonan y berubah menjadi konsonan w sehingga letak fonem vokal yang berubah berada di antara konsonan w dan t. Selanjutnya, pada contoh ketiga, letak fonem vokal yang berubah berada di antara konsonan $\mathrm{n}$ dan $\mathrm{y}$.

\section{$3.1 .2 \approx \mathrm{U} /-\mathrm{K}(\mathrm{V}) \mathrm{K} \#$}

Fonem o di daerah pengamatan Ceruk berkorespondensi dengan fonem $U$ di daerah peng- 
amatan Pulau Laut pada posisi ultima yang letaknya berada di antara konsonan. Korespondensi yang terjadi dapat dikategorikan sebagai korespondensi sangat sempurna karena variasi fonem o menjadi $U$ terjadi pada semua data yang disyarati oleh kaidaho $\approx \mathrm{U} / \mathrm{K}(\mathrm{V}) \mathrm{K} \#$ de ngan sebaran geografis yang sama. Berikut ini adalah tiga contoh sebagai evidensi data yang menunjukkan perbedaan fonologis tersebut.

Tabel 2. Evidensi D ata $0 \approx \mathrm{U} /-\mathrm{K}(\mathrm{V}) \mathrm{K \#}$

\begin{tabular}{|l|l|l|l|}
\hline No. & \multicolumn{1}{|c|}{ Glos } & Ceruk & Pulau Laut \\
\hline 1 & Bunuh & Bunoh & bunUh \\
\hline 2 & Duduk & Dudok & dudU? \\
\hline 3 & Gunung & Gunoy & gunUy \\
\hline
\end{tabular}

Data pada tabel 2 memperlihatkan bahwa untuk glos bunuh / bunoh/ di daerah pengamatan Ceruk berkorespondensi / bunUh/ di daerah pengamatan Pulau Laut. Pada glos duduk / dudok/ di daerah pengamatan Ceruk berkorespondensi dengan / dudU? / di daerah pengamatan Pulau Laut. Sementara pada glos gunung / gunoy/ di daerah pengamatan Ceruk berkorespondensi dengan / gunUy/ di daerah pengamatan Pulau Laut. Korespondensi fonem o menjadi U terletak pada suku kata akhir yang posisinya berada di antara konsonan. Pada glos bunuh, letak perubahan fonem vokal berada di antara konsonan $\mathrm{n}$ dan h. Pada glos duduk, letak perubahan fonem vokal berada di antara konsonan d dan k, kemudian pada daerah pengamatan Pulau Laut, fonem konsonan k berubah menjadi konsonan glotal ( $P$ ) sehingga letak fonem vokal yang mengalami perubahan berada di antara konsonan d dan $\mathrm{P}$. Sementara pada glos gunung, letak fonem vokal yang berubah berada di antara konsonan $\mathrm{n}$ dan $\mathrm{y}$.

\subsection{3 $ə \approx \mathrm{a} / \# \mathrm{~K}(\mathrm{~V})$ -}

Fonem ə di daerah pengamatan Ceruk berkorespondensi dengan fonem a di daerah pengamatan Pulau Laut pada posisi penultima (suku kata kedua sebelum suku akhir) yang letaknya berada setelah konsonan. Korespondensi yang terjadi dapat dikategorikan sebagai korespondensi sangat sempurna karena variasi fonemə menjadi a terjadi pada semua data yang disyarati oleh kaidahəحa/\#K(V)- dengan sebaran geografis yang sama. Berikut ini adalah tiga contoh sebagai evidensi data yang menunjukkan perbedaan fonologis tersebut.

Tabel 3. Evidensi $D$ ata $\partial \approx a / \# K(V)-$

\begin{tabular}{|l|l|l|l|}
\hline No. & \multicolumn{1}{|c|}{ Glos } & Ceruk & \multicolumn{1}{c|}{ Pulau Laut } \\
\hline 1 & Basah & bəsah & basah \\
\hline 2 & Batu & bətu & batu \\
\hline 3 & Daging & dəgen & dagIn \\
\hline
\end{tabular}

Data pada tabel 3 menunjukkan bahwa pada glos basah / bəsah/ di daerah pengamatan Ceruk berkorespondensi / basah/ di daerah pengamatan Pulau Laut. Pada glos batu / botu/ di daerah pengamatan Ceruk berkorespondensi dengan / batu/ di daerah pengamatan Pulau Laut. Sementara pada glos daging / dəgeK/ di daerah pengamatan Ceruk berkorespondensi dengan / dagly/ di daerah pengamatan Pulau Laut. Korespondensi fonem ə menjadi a terletak pada suku kata awal yang posisinya terletak setelah konsonan. Pada glos basah, letak perubahan fonem vokal berada setelah konsonan b. Pada glos batu, letak perubahan fonem vokal juga berada setelah konsonan b, Selanjutnya, pada glos daging, letak fonem vokal yang berubah berada setelah konsonan $d$.

\section{$3.1 .4 \varepsilon \approx \partial /-\#$}

Fonem $\varepsilon$ di daerah pengamatan Ceruk berkorespondensi dengan fonemə di daerah pengamatan Pulau Laut pada posisi akhir ultima. Korespondensi yang terjadi dapat dikategorikan sebagai korespondensi sangat sempurna karena variasi fonem $\varepsilon$ menjadiə terjadi pada semua data yang disyarati oleh

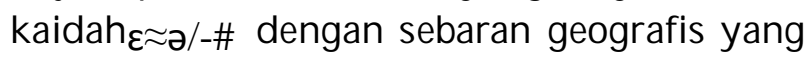
sama. Berikut ini adalah tiga contoh sebagai evidensi data yang menunjukkan perbedaan fonologis tersebut. 
Tabel 4. Evidensi $\mathrm{D}$ ata $\varepsilon \approx \partial /-\#$

\begin{tabular}{|l|l|l|l|}
\hline No. & \multicolumn{1}{|c|}{ Glos } & \multicolumn{1}{|c|}{ Ceruk } & \multicolumn{1}{|c|}{ Pulau Laut } \\
\hline 1 & Dua & duw $\varepsilon$ & duwə \\
\hline 2 & Ia & iy $\varepsilon$ & iyə \\
\hline 3 & Lima & lim $\varepsilon$ & limə \\
\hline
\end{tabular}

Data pada tabel 4 memperlihatkan bahwa pada glos dua / duwe / di daerah pengamatan Ceruk berkorespondensi / duwə/ di daerah pengamatan Pulau Laut. Pada glosia / iye/ di daerah pengamatan Ceruk berkorespondensi dengan / iyə/ di daerah pengamatan Pulau Laut. Sementara pada glos lima / lime/ di daerah pengamatan Ceruk berkorespondensi dengan / limə/ di daerah pengamatan Pulau Laut. Korespondensi fonem $\varepsilon$ menjadiə terletak pada bagian akhir suku kata terakhir.

\section{$3.1 .5 \mathrm{l} \approx \mathrm{i} /-\#$}

Fonem I di daerah pengamatan Ceruk berkorespondensi dengan fonem i di daerah pengamatan Pulau Laut pada posisi akhir ultima. Korespondensi yang terjadi dapat dikategorikan sebagai korespondensi kurang sempurna karena variasi fonem | menjadi i sesuai kaidah $\mathrm{I} \approx \mathrm{i} /$-\# dengan sebaran geografis yang sama hanya ditemukan pada empat contoh saja. Berikut ini adalah empat data yang menunjukkan perbedaan fonologis tersebut.

Tabel 5. Evidensi Data $\mid \approx \mathrm{j} /-\#$

\begin{tabular}{|l|l|l|l|}
\hline No. & \multicolumn{1}{|c|}{ Glos } & \multicolumn{1}{c|}{ Ceruk } & \multicolumn{1}{c|}{ Pulau Laut } \\
\hline 1 & Ini & nI & ini \\
\hline 2 & Istri & binI & bini \\
\hline 3 & Kaki & kakI & kaki \\
\hline 4 & Lelaki & lakI & laki \\
\hline
\end{tabular}

Data pada tabel 5 di atas menunjukkan bahwa pada glos ini / nl / di daerah pengamatan Ceruk berkorespondensi / ini/ di daerah pengamatan Pulau Laut. Pada glos istri / binl/ di daerah pengamatan Ceruk berkorespondensi dengan / bini/ di daerah pengamatan Pulau Laut. Pada glos kaki / kakl/ di daerah pengamatan Ceruk berkorespondensi dengan / kaki/ di daerah pengamatan Pulau Laut. Se mentara pada glos lelaki / lakl/ di daerah peng- amatan Ceruk berkorespondensi dengan/ laki/ di daerah pengamatan Pulau Laut. Korespondensi fonem I menjadi i terletak pada bagian akhir suku kata terakhir.

\subsection{Korespondensi Konsonan}

Berikut ini adalah bentuk-bentuk perbedaan fonologis berupa korespondensi konsonan dalam bahasa Melayu di Ceruk dan di Pulau Laut.

\subsubsection{R $\approx X / \#-, R \approx X /-(K) V$, atau $R \approx X /-(K) V$}

Fonem $\mathrm{R}$ di daerah pengamatan Ceruk berkorespondensi dengan fonem $\mathrm{X}$ di daerah pengamatan Pulau Laut pada posisi penultima dan ultima. Korespondensi yang terjadi dapat dikategorikan sebagai korespondensi sangat sempurna karena variasi fonem $R$ menjadi $X$ terjadi pada semua data yang disyarati oleh kaidah $\mathrm{R} \approx \mathrm{X} / \#-, \mathrm{R} \approx \mathrm{X} /-(\mathrm{K}) \mathrm{V}$, atau $\mathrm{R} \approx \mathrm{X} /-(\mathrm{K}) \mathrm{V}$ dengan sebaran geografis yang sama. Artinya, sesuai kaidah pertama, fonem $\mathrm{R}$ berkorespondensi dengan fonem $X$ pada posisi awal suku kata awal dan pada suku kata terakhir baik yang diikuti vokal saja maupun yang diikuti oleh vokal dan konsonan.

Tabel 6 berikut ini memuat tiga contoh sebagai evidensi data yang menunjukkan perbedaan fonologis tersebut.

Tabel 2. Evidensi Data $R \approx X / \#-, \quad R \approx X /-(K) V$, atau $R \approx X /-(K) V$

\begin{tabular}{|l|l|l|l|}
\hline No. & \multicolumn{1}{|c|}{ Glos } & \multicolumn{1}{|c|}{ Ceruk } & \multicolumn{1}{c|}{ Pulau Laut } \\
\hline 1 & Rumput & RumbUt & XumbUt \\
\hline 2 & Baru & bəRu & baXu \\
\hline 3 & Lurus & luRus & luXus \\
\hline
\end{tabular}

Data pada tabel 6 di atas memperlihatkan bahwa untuk glos rumput / RumbUt/ di daerah pengamatan Ceruk berkorespondensi / RumbUt/ di daerah pengamatan Pulau Laut. Pada glos baru / bəRu/ di daerah pengamatan Ceruk berkorespondensi dengan / baXu/ di daerah pengamatan Pulau Laut. Sementara pada glos lurus / luRus/ di daerah pengamatan Ceruk berkorespondensi dengan / luXus/ di 
daerah pengamatan Pulau Laut. Korespondensi fonem $\mathrm{R}$ menjadi $\mathrm{X}$ ditemukan pada suku kata awal maupun suku kata akhir. Pada glos rumput, perbedaan fonem berada pada posisi awal suku kata pertama. Pada glos baru, perbedaan fonem berada pada suku kata terakhir yang diikuti oleh satu fonem vokal, yaitu $u$. Sementara pada glos lurus, perbedaan fonem berada pada suku kata terakhir yang diikuti oleh satu fonem vokal dan satu fonem konsonan, yaitu u dan s.

\subsection{2 k $\approx$ ?/-\#}

Fonem k di daerah pengamatan Ceruk berkorespondensi dengan fonem glotal ( $P$ ) di daerah pengamatan Pulau Laut pada posisi akhir ultima. Korespondensi yang terjadi dapat dikategorikan sebagai korespondensi sangat sempurna karena variasi fonem k menjadi ? terjadi pada semua data yang disyarati oleh kaidah $\mathrm{k} \approx \mathrm{P} /$-\# dengan sebaran geografis yang sama. Berikut ini adalah tiga contoh sebagai evidensi data yang menunjukkan perbedaan fonologis tersebut.

Tabel 7. Evidensi $\mathrm{D}$ ata $\mathrm{k} \approx$ ?/-\#

\begin{tabular}{|l|l|l|l|}
\hline No. & \multicolumn{1}{|c|}{ Glos } & \multicolumn{1}{c|}{ Ceruk } & \multicolumn{1}{c|}{ Pulau Laut } \\
\hline 1 & Anak & anak & ana? \\
\hline 2 & Anjing & asok & aso? \\
\hline 3 & Buruk & buRuk & buXu? \\
\hline
\end{tabular}

Data pada tabel 7 menunjukkan bahwa pada glos anak / anak/ di daerah pengamatan Ceruk berkorespondensi / anap / di daerah pengamatan Pulau Laut. Pada glos anjing / asok/ di daerah pengamatan Ceruk berkorespondensi dengan / aso? / di daerah pengamatan Pulau Laut. Sementara pada glos buruk / buRuk/ di daerah pengamatan Ceruk berkorespondensi dengan / buXup/ di daerah pengamatan Pulau Laut. Korespondensi fonem $\mathrm{k}$ menjadi $?$ terletak pada posisi akhir suku kata terakhir.

\section{$1.2 .2 \emptyset \approx X /-\#$}

Zero $(\varnothing)$ di daerah pengamatan Ceruk berkorespondensi dengan fonem $\mathrm{X}$ di daerah pengamatan Pulau Laut pada posisi akhir ultima. Korespondensi yang terjadi dapat dikategorikan sebagai korespondensi kurang sempurna karena variasi $\varnothing$ menjadi $X$ terjadi pada semua data yang disyarati oleh kaidah $\emptyset \approx \mathrm{X}$-\# dengan sebaran geografis yang sama. Berikut ini adalah tiga contoh sebagai evidensi data yang menunjukkan perbedaan fonologis tersebut.

Tabel 8. Evidensi D ata $\varnothing \approx X /-\#$

\begin{tabular}{|l|l|l|l|}
\hline No. & \multicolumn{1}{|c|}{ Glos } & \multicolumn{1}{|c|}{ Ceruk } & Pulau Laut \\
\hline 1 & Akar & aka & akaX \\
\hline 2 & Dengar & dəђa & dəђaX \\
\hline 3 & Lempar & lemba & limbaX \\
\hline
\end{tabular}

Data pada tabel 8 di atas memperlihatkan bahwa pada glos akar / aka/ di daerah pengamatan Ceruk berkorespondensi / akaX/ di daerah pengamatan Pulau Laut. Pada glos dengar / dəya/ di daerah pengamatan Ceruk berkorespondensi dengan / dəyaX/ di daerah pengamatan Pulau Laut. Sementara pada glos lempar / I $\mathrm{mba} / \mathrm{di}$ daerah pengamatan Ceruk berkorespondensi dengan / limbaX/ di daerah pengamatan Pulau Laut. Korespondensi $\varnothing$ menjadi $X$ terletak pada bagian akhir suku kata terakhir.

\subsection{3 $\mathrm{t} \approx \mathrm{d} / \mathrm{-}-(\mathrm{K}) \mathrm{VK} \#$}

Fonem $\mathrm{t}$ di daerah pengamatan Ceruk berkorespondensi dengan fonem d di daerah pengamatan Pulau Laut pada posisi ultima. Perubahan fonem t menjadi d hanya berlaku apabila fonem $t$ tersebut didahului oleh konsonan n pada suku kata sebelumnya. Korespondensi yang terjadi dapat dikategorikan sebagai korespondensi kurang sempurna karena variasi fonem t menjadi $d$ sesuai kaidah $\mathrm{t} \approx \mathrm{d} /$ - $(\mathrm{K}) \mathrm{VK} \#$ dengan sebaran geografis yang sama hanya ditemukan pada dua contoh saja. Berikut ini adalah dua contoh yang menunjukkan perbedaan fonologis tersebut. 
Tabel 9. Evidensi Data $\mathrm{t} \approx \mathrm{d} / \mathrm{-}(\mathrm{K}) \mathrm{VK} \#$

\begin{tabular}{|l|l|l|l|}
\hline No. & \multicolumn{1}{|c|}{ Glos } & \multicolumn{1}{|c|}{ Ceruk } & \multicolumn{1}{|c|}{ Pulau Laut } \\
\hline 1 & Bintang & bintan & bindan \\
\hline 2 & Jantung & jəntun & jandon \\
\hline
\end{tabular}

Data pada tabel 9 di atas menunjukkan bahwa pada glos bintang / bintay/ di daerah pengamatan Ceruk berkorespondensi / binday/ di daerah pengamatan Pulau Laut. Pada glos jantung / jəntuy/ di daerah pengamatan Ceruk berkorespondensi dengan / jandoy/ di daerah pengamatan Pulau Laut. Korespondensi t menjadi d terletak suku kata terakhir yang sebelumnya didahului oleh konsonan $\mathrm{n}$.

\subsection{V ariasi Vokal}

Bentuk-bentuk perbedaan fonologis berupa variasi vokal yang ditemukan dalam bahasa Melayu di Ceruk dan di Pulau Laut adalah sebagai berikut ini.

\subsection{1 i Ø/-\#}

Fonem i di daerah pengamatan Ceruk bervariasi dengan zero ( $\varnothing$ ) di daerah pengamatan Pulau Laut pada posisi akhir ultima. Variasi berupa penghilangan satu fonem di akhir kata seperti ini disebut dengan apokop (apocope) (Keraf, 1984:91). Data yang menunjukkan variasi berupa apokop ditemukan pada satu contoh sebagaimana terdapat dalam tabel di bawah ini.

Tabel 10. Evidensi D ata $\mathrm{j}$ Ø/-\#

\begin{tabular}{|l|c|l|l|}
\hline No. & \multicolumn{1}{|c|}{ Glos } & \multicolumn{1}{c|}{ Ceruk } & \multicolumn{1}{c|}{ Pulau Laut } \\
\hline 1 & kelahi(ber) & kəlayi & kəlay \\
\hline
\end{tabular}

Data pada tabel $10 \mathrm{di}$ atas menunjukkan bahwa glos kelahi(ber) / kəlayi/ di daerah pengamatan Ceruk bervariasi dengan / kəlay/ di daerah pengamatan Pulau Laut. Terdapat penghilangan satu fonem vokal di akhir kata tersebut, yaitu fonem i.

\subsection{2 ว a/-K(V)K\#}

Fonem ऽ di daerah pengamatan Ceruk bervariasi dengan fonem a di daerah pengamatan Pulau Laut pada posisi ultima. Data yang menunjukkan variasi tersebut ditemukan pada dua data seperti pada tabel di bawah ini.

Tabel 11. Evidensi Data j a/-K(V)K\#

\begin{tabular}{|l|l|l|l|}
\hline No. & \multicolumn{1}{|c|}{ Glos } & \multicolumn{1}{|c|}{ Ceruk } & \multicolumn{1}{|c|}{ Pulau Laut } \\
\hline 1 & Pegang & pəgən & pəgan \\
\hline 2 & Panjang & panjə⿱ & panjan \\
\hline
\end{tabular}

Data pada tabel 11 di atas menunjukkan bahwa pada glos pegang / pəgっy/ di daerah pengamatan Ceruk bervariasi dengan / pəgan/ di daerah pengamatan Pulau Laut. Selanjutnya, pada glos panjang / panjjy/ di daerah pengamatan Ceruk bervariasi dengan / panjay/ di daerah pengamatan Pulau Laut.

\subsection{3 Ø ว/\#-}

Bentuk variasi vokal lainnya adalah zero (Ø) di daerah pengamatan Ceruk bervariasi de nganə di daerah pengamatan Pulau Laut pada posisi awal penultima. Variasi berupa penambahan satu fonem di awal kata seperti ini dikenal dengan istilah protesis (Keraf, 1984:91). Data yang menunjukkan variasi berupa protesis ditemukan pada satu contoh sebagaimana terdapat dalam tabel di bawah ini.

Tabel 12. Evidensi D ata Ø ə/\#-

\begin{tabular}{|l|l|l|l|}
\hline No. & \multicolumn{1}{|c|}{ Glos } & Ceruk & Pulau Laut \\
\hline 1 & Empat & mbat & əmbat \\
\hline
\end{tabular}

Data pada tabel 12 di atas menunjukkan bahwa glos empat / mbat/ di daerah pengamatan Ceruk bervariasi dengan / ambat/ di daerah pengamatan Pulau Laut. Pada variasi ini, terdapat penambahan satu fonem vokal di awal kata tersebut, yaitu fonem ə.

\subsection{4 Ø a/\#-}

Selain bervariasi dengan fonem ə, zero ( $\varnothing)$ di daerah pengamatan Ceruk juga bervariasi dengan a di daerah pengamatan Pulau Laut pada posisi awal penultima. Artinya, terdapat penambahan satu fonem di awal kata atau protesis (Keraf, 1984:91). Data yang menunjukkan variasi berupa protesis fonem a ditemukan pada satu contoh seperti yang terdapat dalam tabel di bawah ini. 
Tabel 13. Evidensi D ata $\varnothing \sim a / \#-$

\begin{tabular}{|l|l|l|l|}
\hline No. & Glos & \multicolumn{1}{c|}{ Ceruk } & \multicolumn{1}{c|}{ Pulau Laut } \\
\hline 1 & Hantam & Ndam & andam \\
\hline
\end{tabular}

Data pada tabel 13 di atas memperlihatkan bahwa glos hantam / Ndam/ di daerah pengamatan Ceruk bervariasi dengan / andam/ di daerah pengamatan Pulau Laut. Pada variasi ini, terdapat penambahan satu fonem vokal di awal kata tersebut, yaitu fonem a.

\subsection{V ariasi Konsonan}

Adapun variasi konsonan sebagai bentuk perbedaan fonologis bahasa Melayu di Ceruk dan di Pulau Laut diuraikan di bawah ini.

\subsection{1 k g/-(K)VK\#}

Fonem k di daerah pengamatan Ceruk bervariasi dengan $\mathrm{g}$ di daerah pengamatan Pulau Laut pada posisi ultima. A rtinya konsonan tidak bersuara di Ceruk menjadi bersuara di Pulau Laut. Data yang menunjukkan variasi tersebut ditemukan pada satu contoh sebagaimana terdapat dalam tabel di bawah ini.

Tabel 14. Evidensi Datak g/-(K)VK\#

\begin{tabular}{|l|c|l|l|}
\hline No. & Glos & Ceruk & Pulau Laut \\
\hline 1 & Tongkat & tupkat & tungat \\
\hline
\end{tabular}

Data pada tabel 14 di atas memperlihatkan bahwa glos tongkat / tuykat/ di daerah pengamatan Ceruk bervariasi dengan / tungat/ di daerah pengamatan Pulau Laut. Perubahan konsonan dari tidak bersuara menjadi bersuara dipengaruhi oleh bunyi fonem $\mathrm{K}$ pada suku kata sebelumnya.

\subsection{2 p b/\#-}

Fonem $\mathrm{p}$ di daerah pengamatan Ceruk bervariasi dengan $b$ di daerah pengamatan Pulau Laut pada posisi awal penultima. Dalam hal ini, konsonan hambat letup tidak bersuara menjadi bersuara. Data yang menunjukkan variasi tersebut ditemukan pada satu data seperti yang terdapat dalam tabel di bawah ini.
Tabel 15. Evidensi D ata $p \sim b / \#-$

\begin{tabular}{|l|l|l|l|}
\hline No. & \multicolumn{1}{|c|}{ Glos } & Ceruk & Pulau Laut \\
\hline 1 & Pohon & pətan & batan \\
\hline
\end{tabular}

Tabel 15 di atas memperlihatkan bahwa glos pohon / pətay/ di daerah pengamatan Ceruk bervariasi dengan / batay/ di daerah pengamatan Pulau Laut. Posisi fonem konsonan yang dibandingkan tersebut berada di awal kata.

\section{$3.4 .3 \emptyset \sim h /-\#$}

Zero di daerah pengamatan Ceruk bervariasi dengan fonem $\mathrm{h}$ di daerah pengamatan Pulau Laut pada posisi akhir ultima. Variasi berupa penambahan satu fonem di akhir kata seperti ini disebut dengan paragog (Keraf, 1984:92). Data yang menunjukkan variasi berupa paragog ditemukan pada satu contoh sebagaimana terdapat dalam tabel di bawah ini.

Tabel 16. Evidensi Data $\varnothing \sim h /-\#$

\begin{tabular}{|l|l|l|l|}
\hline No. & Glos & Ceruk & Pulau Laut \\
\hline 1 & Besar & bəso & bəsoh \\
\hline
\end{tabular}

Tabel 16 menunjukkan bahwa glos besar / bəso/ di daerah pengamatan Ceruk bervariasi dengan / bəsoh/ di daerah pengamatan Pulau Laut. Terlihat adanya penambahan satu fonem di akhir kata, yaitu fonem $h$.

\subsection{4 Ø ?/-\#}

Selain yang telah diuraikan di atas, zero di daerah pengamatan Ceruk juga dapat bervariasi dengan glotal di daerah pengamatan Pulau Laut pada posisi akhir ultima. Variasi berupa penambahan satu fonem di akhir ini disebut paragog (Keraf, 1984:92). Data yang menunjukkan variasi berupa paragog dengan penambahan fonem $\mathrm{h}$ ditemukan pada dua contoh sebagaimana terdapat dalam tabel di bawah ini.

Tabel 17. Evidensi Data $\varnothing \sim$ ?/-\#

\begin{tabular}{|l|l|l|l|}
\hline No. & \multicolumn{1}{|c|}{ Glos } & \multicolumn{1}{|c|}{ Ceruk } & \multicolumn{1}{c|}{ Pulau Laut } \\
\hline 1 & Ekor & iko & iko? \\
\hline 2 & Kiri & kiRI & kiXI? \\
\hline
\end{tabular}


Tabel 17 menunjukkan bahwa glos ekor/ iko/ di daerah pengamatan Ceruk bervariasi dengan / ikop / di daerah pengamatan Pulau Laut. Sementara padaglos kiri / kiRI/ di daerah pengamatan Ceruk bervariasi dengan / kiXI? / di daerah pengamatan Pulau Laut.

Dari deskripsi perbedaan fonologis bahasa Melayu di daerah pengamatan Ceruk dan Pulau Laut di Kabupaten Natuna di atas, diketahui bahwa perbedaan-perbedaan fonologis yang terjadi pada kedua daerah pengamatan umumnya terletak pada posisi ultima (suku kata terakhir). Pada perbedaan fonologis yang sifatnya teratur berupa korespondensi vokal, ditemukan empat bentuk perubahan bunyi di posisi ultima ( $\varepsilon \approx \mathrm{I}, \mathrm{o} \approx \mathrm{U}, \varepsilon \approx \partial$, dan $\mathrm{I} \approx \mathrm{i}$ ), dan hanya satu di posisi penultima ( $ə \approx a)$. Selanjutnya, pada perbedaan fonologis berupa korespondensi konsonan juga diemukan empat bentuk perubahan bunyi di posisi ultima $(\mathrm{R} \approx \mathrm{X}, \mathrm{K} \approx$ ?, $\varnothing \approx \mathrm{X}$, dan $\mathrm{t} \approx \mathrm{d})$, dan satu di posisi penultima $(\mathrm{R} \approx \mathrm{X}$ ). Pada Perubahan bunyi yang bersifat sporadis berupa variasi vokal, ditemukan dua bentuk perubahan di posisi ultima ( $\sim \varnothing$ dan $\curvearrowright \sim a$ ) dan dua bentuk di posisi penultima ( $\varnothing \sim$ ə dan $\varnothing \sim a$ ). Sementara pada variasi konsonan, ditemukan tiga bentuk perubahan bunyi di posisi ultima (k g, $\varnothing \sim \mathrm{h}$, dan $\varnothing \sim$ ?) dan satu bentuk di posisi penultima $(p-b)$.

\section{PEN UTUP}

Dari uraian pada bagian hasil dan pembahasan di atas, dapat disimpulkan bahwa perbedaan fonologis yang ditemukan antara daerah pengamatan Ceruk dan Pulau Laut ada dua bentuk, yaitu sebagai berikut.

1. Perbedaan berupa perubahan yang sifatnya teratur atau korespondensi. Korespondensi yang ditemukan ada dua bentuk, yaitu korespondensi sangat sempurna dan korespondensi kurang sempurna. Korespondensi sangat sempurna ditemukan pada perubahan fonem $\varepsilon \approx \mathrm{I}, \mathrm{o} \approx \mathrm{U}, \varepsilon \approx \partial$. $\mathrm{R} \approx \mathrm{X}, \mathrm{K} \approx$ ? pada posisi ultima, serta $ə \approx \mathrm{a}$ dan $\mathrm{R} \approx \mathrm{X}$ pada posisi penultima. Sementara korenpondensi kurang sempurna ditemukan pada perubahan fonem $\mathrm{I} \approx \mathrm{i}$ $\emptyset \approx \mathrm{X}$, dan $\mathrm{t} \approx \mathrm{d}$ yang ketiganya berada pada posisi ultima.

2. Perbedaan berupa perubahan yang sifatnya tidak teratur (sporadis) atau variasi. Variasi yang ditemukan yaitu variasi vokal dan konsonan, pada variasi vokal, ditemukan dua bentuk: (a) variasi vokal belakang tengah menjadi vokal pusat rendah ( 0 a) dan (b) variasi berupa penambahan satu fonem di awal kata atau protesis ( $\varnothing \sim$ ə dan $\varnothing \sim a)$. Sementara pada variasi konsonan, ditemukan dua bentuk: (a) variasi konsonan tak bersuara menjadi bersuara ( $\sim \mathrm{g}$ dan $\mathrm{p} \sim \mathrm{b})$ dan (b) variasi penambahan satu fonem di akhir kata atau paragog $(\varnothing-h$ dan $\varnothing ?)$.

Hasil pembahasan yang dimuat dalam tulisan ini masih terbatas pada deskripsi perbedaan fonologis di dua daerah pengamatan bahasa Melayu. Hasil ini tentunya masih dapat dikembangkan lewat penelitian-penelitian lain yang lebih luas dan mendalam. Instrumen yang dipakai dalam penelitian ini juga masi h terbatas pada 200 kosakata Swadesh. Selanjutnya, untuk penelitian semacam ini juga dapat menggunakan tambahan kosakata budaya untuk mendapatkan hasil yang lebih akurat.

\section{DAFTAR PUSTAKA}

BPS. Natuna. 2017. Kabupaten $N$ atuna dalam Angaka 2017. Ranai: BPS Natuna.

Kesuma, Tri Mastoyo Jati. 2007. Pengantar $M$ etode Penelitian Bahasa. Yogyakarta: Carasvatibooks.

Mahsun. 1995. Dialektologi Diakronis: Sebuah Pengantar. Yogyakarta: Gadjah Mada University Press.

Sudaryanto. 1993. M etode dan A neka Teknik A nalisis Bahasa. Yogyakarta: Duta Wacana University Press. 
